University of Maryland Francis King Carey School of Law

DigitalCommons@UM Carey Law

10-14-1993

\title{
Partner Notification and the Threat of Domestic Violence Against Women with HIV Infection
}

Karen $\mathrm{H}$. Rothenberg

University of Maryland School of Law, krothenberg@law.umaryland.edu

Richard L. North

Follow this and additional works at: https://digitalcommons.law.umaryland.edu/fac_pubs

Part of the Health Law and Policy Commons, and the Law and Gender Commons

\section{Digital Commons Citation}

Rothenberg, Karen H. and North, Richard L., "Partner Notification and the Threat of Domestic Violence Against Women with HIV Infection" (1993). Faculty Scholarship. 162.

https://digitalcommons.law.umaryland.edu/fac_pubs/162

This Article is brought to you for free and open access by the Francis King Carey School of Law Faculty at DigitalCommons@UM Carey Law. It has been accepted for inclusion in Faculty Scholarship by an authorized administrator of DigitalCommons@UM Carey Law. For more information, please contact smccarty@law.umaryland.edu. 


\section{SOUNDING BOARD}

\section{PARTNER NOTIFICATION AND THE THREAT OF DOMESTIC VIOLENCE AGAINST WOMEN WITH HIV INFECTION}

The Centers for Disease Control and Prevention (CDC) reports that women constitute the fastestgrowing group of people with AIDS in the United States. Women now represent 13 percent of reported cases. Approximately 80,000 women of childbearing age are infected with the human immunodeficiency virus (HIV), and as many as 14,000 women will have been given a diagnosis of AIDS by the end of 1993. ${ }^{1}$

Over 70 percent of infected women are from minority groups: 51 percent are black, and almost 20 percent are Hispanic. Intravenous drug use was the mode of transmission in over 50 percent of the cases, and sexual contact with an HIV-infected partner in 30 percent.

The general assumption is that it makes good sense,

Reprinted from the New England Journal of Medicine 329:1194-1196 (October 14), 1993 
from the standpoint of public health, for a patient to notify sexual partners of his or her positive HIV status. Three common justifications are (1) to protect uninfected partners from a possible future infection; (2) to inform those who have been exposed so that they can be tested and, if positive, avail themselves of appropriate medical care; and (3) to bring into the public health system people whose behavior puts them at risk of contracting (or transmitting) $\mathrm{HIV}$ and to counsel them to change their behavior. If a patient does not disclose her positive status to partners, health care providers and public health authorities are expected to trace and notify them.

Notification protocols must be reexamined in the light of another epidemic affecting women - the epidemic of domestic violence. The estimated number of battered women in the United States ranges from 1.6 million to 12 million a year. ${ }^{2,3}$ Many women learn of their HIV infection during prenatal care, and 25 to 63 percent of women who have been battered undergo abuse during pregnancy, including blows to the abdomen, injuries to the breasts and genitals, and sexual assault. ${ }^{2}$ In one study of violence and substance use during pregnancy, a pregnant woman's risk of being battered was associated with her use of alcohol and her partner's use of illicit drugs during the pregnancy, even when the researchers controlled for socioeconomic factors and a history of violence. ${ }^{*}$

The National Association of People with AIDS reports a strong link between violence and AIDS. In a recent survey conducted by the association, patients with AIDS ranked the threat of violence as a major concern. Seventeen percent of all women in the survey and 25 percent of Hispanic women reported violence in the home. ${ }^{5}$ The risk of violence has also been emphasized by researchers investigating the failure of AIDS-prevention programs for women. Promoting the use of condoms (the main strategy for reducing the risk of sexual transmission) has been linked to an increased risk of violence for the most vulnerable women, who may already be victims of sexual or physical abuse. ${ }^{6,7}$

The connections among domestic violence, drug abuse, and AIDS suggest that thousands of women with HIV infection may be at risk of harm from their partners if the partners are informed of the infection. We are aware of two women who were shot and many others who were injured or abandoned after revealing to their partners that they were infected with HIV. To the best of our knowledge, there have been no studies of assault or threats of violence by a sexual partner after notification of HIV status. Despite the lack of data, the CDC notes in its brochure on patient counseling that the patient should anticipate a "hostile reaction" from a partner on learning that he or she has been exposed to infection. ${ }^{8}$ Nonetheless, the CDC continues to urge that all partners be notified of a likely exposure.

When there is a risk of violence, how should the health care provider respond? How can the physician reconcile the public health strategy of notifying all partners with the duty to do no harm to the patient, especially when the patient reports a strong possibility of violence should her partrer learn of her HIV infection?

An analysis of the potential for legal liability offers little help, since the physician has duties to the patient and to the patient's partner, although to different degrees, if there is a foreseeable risk of harm to either party. Instead, we propose as guiding principles four ethical tenets that underlie the relationship between physician and patient: beneficence, nonmaleficence (doing no harm), respect for autonomy, and confidentiality. Beneficence compels the physician to maintain a loyalty to the patient that is unencumbered by nonmedical considerations. Nonmaleficence directs the physician not only to address the manifestations of disease but also to protect the patient from additional harm. Respect for autonomy means encouraging self-determination on the part of the patient. Confidentiality requires deference to the patient's concern for privacy. In combination these tenets direct us to make the interests of the patient our primary focus. Moreover, we should show due concern for the relationships valued by the patient.

We propose an analytic framework for decisions about partner notification that is consistent with the. physician's primary ethical concern for the patient. In making these decisions, physicians must balance both the likelihood and the seriousness of potential harm to the parties in choosing whether to breach confidentiality against the wishes of the patient. Although the seriousness of HIV transmission cannot be overstated, a high risk that an infected patient will be subject to immediate violence or death outweighs the risk that she will transmit HIV to her partner. As uncomfortable as some physicians may feel about raising the difficult issues of sex and drug use, they should be discussed if there is a risk of violence.

In addition to balancing the seriousness of potential harms, the physician must weigh the risk of occurrence before deciding on a course of action. For example, there is considerable scientific evidence that the risk of HIV transmission from women to men through vaginal sex is quite low as compared with the risk of transmission from men to women. ${ }^{9,10}$ If transmission by sexual contact is the only risk faced by a male partner, the threat of violence to the patient may outweigh the obligation to notify the partner. Indeed, male partners of HIV-infected women may be infected already. When it can be ascertained that the partner is already infected, notification is less urgent. The risk of physical harm to the female patient from her partner may be greater than the potential benefit of warning the partner. If an HIV-infected woman is at high risk of violence from a sexual or needlesharing partner, the physician should weigh this risk against that of HIV transmission. 
The decision to breach confidentiality is exceedingly problematic. Medical ethicists argue that the burden of persuasion falls on the physician who wishes to disclose information about the patient. "Although health care providers have a duty to protect third parties from harm, partner notification may discourage women from seeking HIV testing and counseling because of the fear that their partners may learn of their infection and do them physical harm. If the risk of domestic violence is great, the HIV-infected woman should be protected from that risk before partner notification is recommended or undertaken. Clinical assessment screens are effective in identifying the occurrence, frequency, and severity of abuse suffered by women. ${ }^{12}$ Such screening should be used before consideration is given to notifying a partner over the objection of the patient.

When the patient's partner is also a patient of the physician, the physician would appear to have identical obligations to both patients. Obviously, it is impossible to ascribe a greater value to one patient than to another. Nevertheless, we believe a distinction can be made in terms of the need for protection. Whereas men have available the means to protect themselves from HIV infection, women are often powerless to protect themselves from male-to-female transmission and are more susceptible than men to infection through vaginal intercourse. Decisions about partner notification need to be made in the context of many factors, one of which may be the vulnerability of the female patient to abuse. At the very least, informed consent must include a warning to the patient that her partner may be notified if she has a positive test for HIV.

To minimize the risk of violence to an HIV-infected woman, pre- and post-test counseling must include a safety plan if the physician intends to notify the partner. Notification must be delayed until a plan is in place to protect the patient from harm. Of course, if there is no indication of a risk of violence against the woman, the provider should follow public health directives with respect to partner notification.
In addition to offering an approach to resolving the conflict that partner notification may raise for health care providers treating women with HIV infection, we also call for studies of the connection between domestic violence and partner notification in the context of the HIV epidemic. The epidemics of AIDS and domestic violence intersect, creating a new challenge for the health care community. To meet this challenge, physicians and public health officials need to address the threat of abuse in formulating policies and practices of partner notification in the case of HIV-infected women. To ignore the possibility of violence is to run the risk of placing HIV-infected patients in harm's way.

\section{University of Maryland \\ School of Law}

Baitimore, MD 21201-1786
Richard L. North, J.D. KAREN H. ROTHENBERG, J.D., M.P.A.

\section{REFERENCES}

1. Projections of the number of persons diagnosed with AIDS and the number of immunosuppressed HIV-infected persons - United States, 1992-1994. MMWR Morb Mortal Wkly Rep 1992;41(RR-18).

2. Helton AS, McFariane J, Anderson ET. Battered and pregnant: a prevalence study. Am J Public Health 1987;77:1337-9.

3. American Medical Association, Council on Scientific Affairs. Violence against women. Chicago: American Medical Association, 1991.

4. Amaro $H$, Fried LE, Cabrai H, Zuckerman B. Violence during pregnancy and substance use. Am J Public Health 1990;80:575-9.

5. HIV in America: a report by the National Association of Peopie with AIDS. Washington, D.C.: National Association of People with AIDS, 1992

6. Weissman G. AIDS prevention for women at risk: experience from a National Demonstration Research Project. J Primary Prev 1991;12:4952.

7. Worth D. Sexual decision-making and AIDS: why condom promotion among vulnerable women is likely to fail. Stud Fam Plann 1989;20:297307.

8. Department of Health and Human Services. Voluntary HIV counseling and testing: facts, issues and answers. Atlanta: Centers for Disease Control, 1990.

9. Update: acquired immunodeficiency syndrome - United States, 1992. MMWR Morb Mortal Wkly Rep 1993;42:47-57.

10. Padian NS, Shiboski SC, Jewell NP. Female-to-male transmission of human immunodeficiency virus. JAMA 1991;266:1664-7.

11. Beauchamp TL, Childress JF. Principles of biomedical ethics. 2nd ed. New York: Oxford University Press, 1983.

12. McFarlane J, Parker B, Soeken K, Bullock L. Assessing for abuse during pregnancy: severity and frequency of injuries and associated entry into prenatal care. JAMA 1992;267:3176-8. 